of history and to our continuity with it. Hence his love of historical biography, legal and otherwise. Hence the thoughtfully inscribed postcards from the world's great museums. Hence his beloved Locust Mountain Farm - "just the other side of the hill," he used to say, "from where Tom Jefferson had his place."

Perhaps because Professor Lillich put such a high premium on collegial friendship and life's continuities, I am at a loss to accept his death even as I write. As I continue, in his memory, to edit the PAIL book series that he started, I still half-expect his constant reminders about the importance of properly placed adverbs and accurate footnotes. As his colleague in one professional association or another, I have yet completely to grasp why the phone does not ring with principled indignation at this or that intrigue or outrage. And it still has not really sunk in that, as his intellectual companion and friend generally, I am to be denied the penetrating liberal argument and that familiar "etc., etc."

BURNS H. WESTON*

\title{
JOHN H. MCNEILL (1941-1996)
}

Last October, a great many of us said our farewells to John $\mathrm{H}$. McNeill at Arlington National Cemetery. His death had not been a total surprise, since he had gone through a long and difficult illness. But it was still very hard to accept the thought that we would no longer have him with us.

Jack McNeill was a fine scholar. He earned an LL.M. and a Ph.D. from the London School of Economics, and a diploma from the Hague Academy. He taught at the Naval War College, the Johns Hopkins School of Advanced International Studies, and Georgetown Law School. He served as a consultant to the Ford Foundation, the International Atomic Energy Agency and Amnesty International. He was a member of the Board of Editors of the American Joumal of International Law, and a member of the Executive Council of The American Society of International Law. His list of publications is long and impressive.

Jack McNeill was a seasoned negotiator and counselor. He was the senior career attorney in the Department of Defense and a member of the Senior Executive Service. As Senior Deputy General Counsel in DOD, he was responsible for the legal aspects of all the Department's international activities-operational deployments, disaster relief, security assistance, intelligence activities, and so on. He was a valuable member of many U.S. negotiating teams, both for DOD and previously for the Arms Control and Disarmament Agency (ACDA). He received a number of awards from the U.S. Government, including two presidential-rank awards.

Jack McNeill was a great asset for the United States in the conduct of its international responsibilities. He played an important role in the negotiation of several major arms control agreements. He was a recognized expert on the law of the sea and the law of armed conflict, and a significant factor in ensuring DOD's compliance with that law. He was a trusted colleague and point of contact for all of us in the State Department, the National Security Council, ACDA and other agencies that had legal business to conduct with DOD. He was well-known and well respected in diplomatic circles as a strong, but constructive, representative of the United States. He argued for the United States before the International Court of Justice and represented us in International Red Cross conferences.

But most of all, Jack McNeill was a great friend and colleague. He was never petty or parochial. He was always courteous and self-effacing. He would always go well out of his

* Of the Board of Editors. 
way to find a reasonable solution to every problem and to take seriously every reasonable point of view. Doing the right thing was more important to him than gaining some temporary bureaucratic or personal advantage. He never hesitated to give his best and most honest advice, whatever the personal consequences.

The world badly needs more people like Jack McNeill. Now we have one less. We cannot bring him back, but we can try to remember what it was that made him such a fine human being and emulate that ourselves. So, farewell, good friend-we are so sorry to lose you, but so very glad to have traveled part of the journey with you.

MichAEL J. MATHESON*

\section{CORRESPONDENCE}

\section{To THE CO-EDITORS IN CHIEF:}

The Lowenfeld-Clagett discourse about Helms-Burton (Agora: The Cuban Liberty and Democratic Solidarity (LIBERTAD) Act, 90 AJIL 419 (1996)) is interesting and learned, but seems to me to miss one obvious - and probably decisive-factor in the debate about the legality of the Act. Perhaps only a few realize it, but the Organization of American States exists; the United States, Mexico and Canada are all members; and all are bound by the Charter of the OAS. That Charter provides in what seem to be unambiguous terms against intervention in the affairs of other member states. Article 18 reads: "No State or group of States has the right to intervene, directly or indirectly, for any reason whatsoever, in the internal or external affairs of any other State." Article 19 adds: "No State may use coercive measures of an economic or political nature . . . to force the sovereign will of another State."

It seems clear that the intent of Helms-Burton is precisely to intervene in the affairs of several OAS member states (inter alia) and to force their "sovereign will." The United States can of course enact a law of this sort, but it will violate a treaty commitment in so doing.

SEYMOUR J. RuBIN†

\section{To THE CO-EDITORS IN CHIEF:}

I was deeply surprised to read in the July 1996 issue of the Journal the Editorial Comment of Judith Hippler Bello on dispute settlement in the WTO (90 AJIL 416 (1996)). The view that WTO rules "are simply not 'binding' in the traditional sense," that the WTO is "essentially a confederation [?] of sovereign national governments" that "relies upon voluntary compliance," and that "[c]ompliance with the WTO . . remains elective" (90 AJIL at 416-17) negates the common effort to transform the GATT's weak, predominantly power-oriented system of economic relations into a legally binding order, governed by an international organization (the WTO) and subject to a quasi-judicial dispute-settlement mechanism.

It is true that the spirit of the system is to seek a balance among the economic interests of the parties, but not in disregard of legal obligations freely entered into as a part of the deal. Mutual accommodation of interests has to be sought at the stage of consulta-

\footnotetext{
* Acting Legal Adviser, U.S. Department of State.

'It might also be noted here that, on August 23, 1996, the Inter-American Juridical Committee, in response to a request for an opinion by the OAS General Assembly, unanimously approved its Resolution CJI/RES.II$14 / 96$, to which was annexed the committee's opinion on the legality under international law of legislation "whose content is similar to that of the Helms-Burton Act." Focusing on the protection of property rights of nationals and the extraterritorial exercise of jurisdiction, the committee concluded that in these "significant areas . . . the bases and potential application of the legislation . . . are not in conformity with international law." OAS Doc. CJI/SO/II/doc.67/96, rev.5, at 6. The opinion is reprinted in 35 ILM 1322 (1996).

$\dagger$ Of the Board of Editors.
} 